Nloman 2019, 37(1), 57-64

Revista de Psicologia, Ciències de l'Eduació i de l'Esport

ISSN: $1138-3194$

CFacultat de Psicologia, Ciències de l'Educació i de l’Esport Blanquerna

Universitat Ramon Llull

(c) (1) $\$$

NC SA

\title{
Suspended lunge exercise: assessment of forces in different positions and paces
}

\author{
Joan Aguilera-Castells ${ }^{1}$, Bernat Buscà ${ }^{1}$, Javier Peña ${ }^{2}$, Azahara Fort-Vanmeerhaeghe ${ }^{1}$, \\ Mònica Solana-Tramunt ${ }^{1} \&{\text { Jose } \text { Morales }^{1}}^{2}$ \\ ${ }^{1}$ Ramon Llull University \\ ${ }^{2}$ University of Vic - Central University of Catalonia
}

Received: 22 oct 2018

Accepted: 8 apr 2019

Suspended lunge exercise: assessment of forces in different positions and paces

\begin{abstract}
Summary. The forces exerted on a suspension device have been examined in the upper body exercises such as push-ups or inverted row. However, there is a lack of evidence with regard to the effects of a suspension device on force production in lower limb exercises. For this reason, this aim of this study was to determine the effects of body position, contraction patterns and pace on force production by the lower limb during the execution of suspended lunge exercises. Ten physically active male university students $(n=10$, age $=23.70 \pm 2.83$ years old $)$ performed sixteen suspended lunges in four different positions and at three different paces (60, 70, and 80 beats per minute). A load cell was used to assess the forces exerted on the suspension device. Force data were analysed with factorial repeated measurements (ANOVA). Significant main effects for position in concentric force $(p=.000)$, average force $(p=.002)$, and for frequency in peak force $(p=.004)$ were found. Peak force was significantly higher in all positions for dynamic contraction type than for isometric suspended lunge. In conclusion, a greater distance of the feet, frequencies around 70 beats per minute and the dynamic contraction type all contributed to enhancing the forces exerted on the suspension strap in the performance of the lunge exercise.
\end{abstract}

Key words: Suspension training; lower-body strength; strain gauge

\section{L'exercici de lunge en suspensió: valoració de les forces en diferents posicions i ritmes}

Resum. Les forces exercides sobre un dispositiu de suspensió han estat examinades en exercicis com les flexions de braços o el rem invertit. No obstant això, hi ha una manca d'evidències investigant l'efecte dels dispositius de suspensió sobre la producció de força a l'extremitat inferior. Per aquesta raó, l'objectiu de l'estudi va ser determinar els efectes de la posició corporal, els règims de contracció i la velocitat d'execució sobre la producció de força de l'extremitat inferior durant l'exercici del lunge en suspensió. Es van reclutar joves universitaris físicament actius $(n=10$, edat $=23.70 \pm 2.83$ anys) per fer setze lunges en suspensió en quatre posicions i tres ritmes diferents (60, 70, i 80 batecs per minut). Es va utilitzar una cèl-lula de força per valorar les forces exercides sobre el dispositiu de suspensió. Les dades de força es van analitzar amb l'ANOVA factorial de mesures repetides. Es va obtenir un efecte principal per la posició en la força concèntrica $(p=.000)$, força mitjana $(p=.002)$, i per la freqüència en el pic de força $(p=.004)$. El pic de força va ser significativament més alt durant la contracció dinàmic en comparació amb la isomètrica en totes les posicions. Les posicions amb amplituds més grans entre cames, freqüències al voltant dels 70 batecs per minut i el règim de contracció dinàmic milloren les forces exercides sobre el dispositiu de suspensió en l'exercici de lunge.

Paraules clau: Entrenament en suspensió; força tren inferior; galga de força

Correspondence

Bernat Buscà

Department of Sports Sciences, Ramon Llull University,

FPCEE Blanquerna

Ramon Llull University

bernatbs@blanquerna.url.edu 


\section{Introduction}

In recent years, the use of instability resistance training in the field of sports training and fitness activities has been gradually gaining prominence over more traditional resistance training. The main reasons for the method's increased popularity include its simplicity, (as it requires nothing more than body weight in terms of load), its specificity, and its high degree of transferability to actions in sporting competition. The use of unstable surfaces has been shown to be effective in the past for use in untrained populations, satisfactorily replacing the use of external loads to achieve strength benefits (Sparkes \& Behm, 2010; Tomljanovic, Spasic, Gabrilo, \& Uljevic, 2011). Strength gains in bench press and back squat exercises have been shown to be associated with increases in one-repetition maximums when performed under unstable conditions, after six to eight weeks of training (Marinkovic, Bratic, Ignjatovic, \& Radovanic, 2012; Maté-Muñoz, Monroy, Jodra Jiménez, \& Garnacho-Castaño, 2014). Nevertheless, when comparing force outputs for exercises under unstable conditions to data for exercises done on even surfaces, the values are lower for instability exercises like the squat or the deadlift (Chulvi-Medrano et al., 2010; Saeterbakken \& Fimland, 2013). With regard to muscle activation, unstable surfaces demand a higher degree of activity in most of the muscle groups participating in exercise than is the case on stable surfaces (Anderson, Gaetz, Holzmann, \& Twist, 2013; Escamilla et al., 2010). This increased muscle activation, caused by increased instability, can be achieved by reducing the contact area and contact points on the surface, thus leading to greater reliance on the core muscles when there are larger demands for stabilization and balance (Snarr, Hallmark, Nickerson, \& Esco, 2016). For this reason, both in the field of strength and conditioning and in rehabilitation, the use of suspension devices (SD) has become more commonplace, due to the ability of these devices to help boost muscle activity and increase exercise demands.

Suspension training (ST) generates instability by using an SD consisting of two straps joined by a singlepoint anchor with two handles at its ends similar to rings. The degree of instability created by this SD and its effects on muscle activation have been analysed in exercises such as push-ups (Calatayud et al., 2014; McGill, Cannon, \& Andersen, 2014a), inverted rows (McGill, Cannon, \& Andersen, 2014b; Melrose \& Dawes, 2015) and the plank (Atkins et al., 2015; Byrne et al., 2014), all of which feature a great deal of involvement of the upper body muscles. However, there is less data when it comes to the exercises used to strengthen the lower extremities, among which lunges (the traditional exercise done without instability) and variations on them are some of the most widespread training activities (McCurdy, Langford, Cline, Doscher, \& Hoff, 2004). A lunge is a unilateral, closed kinetic chain exercise. It is functional and involves the use of multiple joints (Boudreau et al., 2009; Jönhagen, Halvors- en, \& Benoit, 2009). Lunges involve the constant activation of the gluteus, quadriceps, hamstrings and the triceps surae during the different contraction regimes (Boudreau et al., 2009). Several studies have recorded muscular activity during the execution of lunges and their variations in order to quantify the load supported by the forward leg during these exercises (Ekstrom, Donatelli, \& Carp, 2007; Jönhagen, Ackermann, \& Saartok, 2009). These studies, however, did not analyze the implications of differences in positioning or of variations in pace for the execution of a single exercise. The literature provides evidence that contraction types and execution speeds are parameters that should be taken into account when modifying lunge characteristics. Jakobsen, Sundstrup, Andersen, Aagaard, and Andersen (2013) examined lunges to test the effects of differences in execution speed (low vs. high) on the levels of activation of the muscles involved. Prior research on ST has also examined the effects of positioning, contraction regimes and speed of execution in different exercises. Borreani et al. (2015) and Calatayud et al. (2014) analysed the activation of the upper extremity and core muscles during the execution of suspended push-ups at different heights (10 $\mathrm{cm}$ and $65 \mathrm{~cm}$ ), observing that the level of muscular activation was higher when push-ups were performed in suspension at $10 \mathrm{~cm}$ from the floor than when they were done at a height of $65 \mathrm{~cm}$. Similarly, McGill et al. (2014a, 2014b) found that as they modified the angle of inclination of push-ups and inverted rows by increasing the strap length, the degree of activation of the muscles analysed increased significantly.

In ST research, the effects brought about by changing body positions and by varying contraction regimes and execution speeds are traditionally assessed using measurements of force and muscular activity. To evaluate muscle activation, electromyography (EMG) is commonly used, often in the form of Maximum Voluntary Isometric Contraction (MVIC) tests, but the use of dynamometers or strain gauges to measure the strain forces constitute a more affordable and practical way to evaluate force production, because ST exercise use body weight and the initial moment of inertia to generate muscle demands (Gulmez, 2017; Melrose \& Dawes, 2015). Therefore, the magnitude of the forces generated depends on the degree of instability caused by the SD and body position (Maté-Muñoz et al., 2014). Melrose and Dawes (2015) used a dynamometer to quantify load when performing an isometric suspended inverted row. To modify body position, they used four different inclination angles. The researchers observed that as the angle of inclination between the subject and the ground increased (from $30^{\circ}$ to $75^{\circ}$ ), body mass resistance also augmented from $37.4 \%$ to 79.4\%. Furthermore, Gulmez (2017) used a strain gauge or load cell to gather data on body mass resistance at different angles of inclination during participants' execution of a number of SD push-ups . Body mass resistance was found to increase (from $36.8 \%$ to $75.3 \%$ in elbow flexion and from $11.9 \%$ to $50.4 \%$ in elbow 
extension) when the angle of the TRX straps was modified (from $45^{\circ}$ to $0^{\circ}$ ).

To the best of our knowledge, quantification of body mass resistance has only been calculated in a few upperbody ST exercises, such as push-ups and inverted row exercises (Gulmez, 2017; Melrose \& Dawes, 2015). For this reason, it seemed worth examining the quantification of loads in different lower body ST exercises. Therefore, this research was undertaken with the main aim of determining the lower limb force production during suspended lunge (SUL) exercises, and secondarily to compare force production achieved with different body positions (thanks to alterations in the height of the suspension device and in the distance between the suspended lower limb and the support lower limb), different contraction types (isometric and dynamic) and different paces of exercise $(60,70$ and 80 beats per minute $(\mathrm{bpm}))$. The first hypothesis was that the strength production of the lower limb in suspension would increase along with as the height and distance between the suspension device and the lower limb in contact with the ground. Secondly, it was hypothesised that increasing execution speeds would also be associated with increases in the force produced during dynamic actions (60, 70 and $80 \mathrm{bpm}$ ) and that these dynamic contractions require a greater production of force than isometric movements. The final hypothesis was that body mass resistance would significantly increase as the distance between the participants' feet and the height of the suspended foot increase.

\section{Methods}

\section{Design}

A repeated measures design was used to compare force production under 16 different conditions of the SUL exercises and thus to determine if the resulting force increased when the position, the contraction regime, and the execution speed were modified. The SUL exercise was carried out using the TRX Suspension train$\mathrm{er}^{\mathrm{TM}}$ device. An S-Type Load Cell force sensor was used to obtain strength extension values for the suspended lower extremity. To determine the effect of SD on force production, four body positions were used (TRX_height with respect to the floor $_{(\mathrm{cm})}$-distance between lower support limb and in suspension $(\mathrm{cm})$ : 1) TRX_40-60, 2) TRX_40-80, 3) TRX_60-60, and 4) TRX_60-80. In each of these positions, one isometric and 3 dynamic SULs were performed at 60, 70 and $80 \mathrm{bpm}$.

\section{Participants}

Ten healthy and physically active male subjects (mean age $=23.70 \pm 2.83$ years, height $=1.83 \pm .043 \mathrm{~m}$, weight $=79.30 \pm 10.85 \mathrm{~kg}$, body mass index $=23.58 \pm 2.42$ $\mathrm{kg} \cdot \mathrm{m}^{-2}$, thigh length $=40.90 \pm 2.02 \mathrm{~cm}$, leg length $=$ $53.40 \pm 2.46 \mathrm{~cm}$ ) were voluntarily recruited for the study. All the participants not presenting a height between $1.77 \mathrm{~m}$ and $1.87 \mathrm{~m}$, as well as those who pre- sented diseases and/or pain related to the cardiovascular, musculoskeletal and neuromuscular apparatuses, were excluded. All the participants received clear information on the research protocol and signed the informed consent, having previously read the information document. The ethics committee of the Ramon Llull University of Barcelona approved the development of this study, which was conducted in accordance with the latest version of the declaration of Helsinki (revised in Fortaleza, Brazil, 2013).

\section{Procedures}

The research was carried out in two sessions. The familiarisation and the experimental sessions were held the same day of the week. All the exercise conditions and the order of the participants were randomly assigned. During the familiarisation session, the anthropometric data on the different subjects were collected, and each participant was also asked to identify his dominant leg, defined here as the participant's preferred kicking leg (Meylan, Nosaka, Green, \& Cronin, 2010). The length of the thigh and the leg were also measured, in accordance with the ISAK (2001) protocol. Additionally, in this session participants were given training in the correct mechanics of SUL exercises to be done under all the analysis conditions.

Participants were asked not to perform any intense physical activity during the 12-hour span prior to the experimental sessions. Participants performed the SUL with the TRX Suspension trainer (Fitness Anywhere, San Francisco, CA), with a distance of $40 \mathrm{~cm}$ and 60 $\mathrm{cm}$ between the ground and the device's strap. The TRX $^{\circledR}$ anchor point was located on the ceiling at a height of $2.95 \mathrm{~m}$ from the ground. Participants performed the 16 variations of the movement in two blocks (first block TRX_40 cm and second block TRX_60 $\mathrm{cm})$. During each block, the distance between the lower limbs, contraction types (isometric and dynamic) and the execution speeds (60, 70 and $80 \mathrm{bpm}$ ) were modified. Participants performed a set of three repetitions of the isometric SUL (three seconds at the top position, ten seconds at the bottom position) and a set of five repetitions of the dynamic SUL with 90 seconds of rest between each SUL condition. The execution speed in the dynamic SUL was established using a metronome (the app Pro Metronome, version 3.13.2; EUMLab-Xannin Technology Gmbh., Hangzhou, China).

Standarisation of the SUL exercises was ensured by asking the participants to cross their arms over their chests and to keep their trunks in a neutral position. The heel of the lower extremity in contact with the ground had to be placed in front of the marks indicating the different distances $(60 \mathrm{~cm}$ and $80 \mathrm{~cm})$. The sole of this foot had to be completely flat on the ground. The foot of the non-dominant lower extremity was placed inside the device handle, with a slight plantar flexion of the ankle joint (Figure 1). To obtain better control of the SUL movement range, a WSB 16k-200 


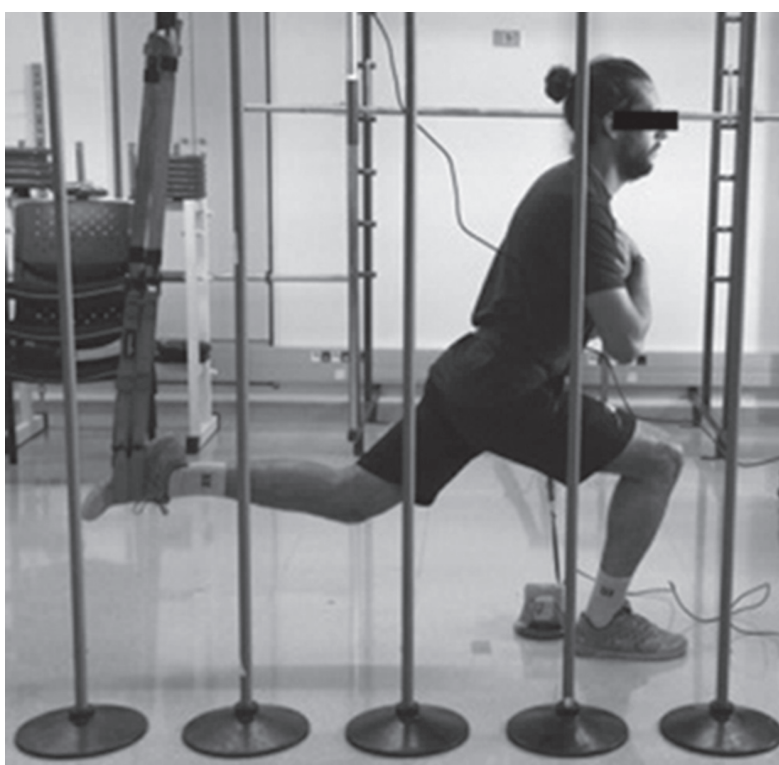

Figura 1. Standardised position during suspended lunge.

position encoder was used (ASM Inc., Moosinning, DEU), and all the SUL exercises were recorded at $30 \mathrm{fps}$ with an iPhone 6 Plus (Apple Inc., Cupertino, CA). To control the movement of the suspended lower limb and the participants' trunk movements and to prevent the knee from going past the toes during the flexion movement, five plastic poles were used as reference marks. They were placed at a distance of $40 \mathrm{~cm}$ from one another and aligned with the camera's line of vision (Payton, 2008).

If a participant's execution of any of the SUL was incorrect, researchers asked him to stop the exercise, and then (respecting the 90 seconds of rest between sets) to perform the SUL again. However, only those repetitions of SULs that met the standard criteria for the movement were analysed.

\section{Measures}

The forces exerted on the suspension strap during SULs were assessed with a $200 \mathrm{HZ}$ S-Type Load Cell strain gauge CZL301C (Phidgets Inc., Alberta, CAN), which was placed between the anchorage point and the TRX. The load cell was calibrated following the manufacturer's recommendations. According to Tiainen et al. (2004) and Vivodtzev et al. (2006), force sensors are a valid and reliable tool to measure muscle strength. The data gathering process was performed using the DA 100C transducer force sensor (BIOPAC System, INC., Goleta, CA) connected to the BIOPAC MP-150 (BIOPAC System, INC., Goleta, CA). The information was transferred to AcqKnowledge software (Version 4.2 for Windows 7; BIOPAC System, INC., Goleta, CA), where a force/time curve was displayed. The average recorded force was calculated for each of the repetitions in the concentric phase, the eccentric phase and the concentric/eccentric phases. The variables of concentric force, eccentric force and average force were expressed as the mean total of the average force of each of the repeti- tions in the concentric phase, the eccentric phase and the concentric/eccentric phase, respectively. The peak force variable was calculated for both the dynamic SUL and the isometric SUL and was expressed as the average value of the maximum force production in each of the repetitions (five reps for dynamic suspended and three reps for isometric suspended). Additionally, the peak force of the isometric conditions was normalised for each participant using the following equation: load norm (\%) = load /body weight x 100 (Gulmez, 2017). The normalised values were expressed as a percentage of the total load.

\section{Statistical Analysis}

Descriptive statistical analysis and frequencies were used to describe the sample. Descriptive statistical methods were used to calculate the mean and the standard deviations. To test the normality of the sample, the Shapiro-Wilk hypothesis test for samples of below 50 subjects was performed. The number of subjects recruited was based on effect size $0.4 \mathrm{SD}$ with an $\alpha$ level of .05 and power at .95, calculated with the G Power Software (University of Dusseldorf, Germany). The analysis of the factorial variance (Position [height distance_TRX] X Frequency [60, 70 and $80 \mathrm{bpm}$ ] and Position [height_distance_TRX] X Contraction type [dynamic and isometric]) of repeated measurements (ANOVA) was used. The Greenhouse-Geisser correction was applied when sphericity was violated (Mauchly's Test). A One-way ANOVA test was used to compare the body mass resistance $(\mathrm{kg})$ recorded in the different positions under isometric conditions. In both analyses, Post-hoc analyses with Bonferroni corrections were carried out when significant effects were assumed. The effect of the size was indicated with partial eta squared $\left(\eta_{\mathrm{p}}{ }^{2}\right)$, with cut values of .01, .06, and .14 for a small, medium and large effect, respectively (Cohen, 1988). The significance level was established at $p<.05$. The results were expressed using mean \pm standard deviation. Statistical analysis were carried out using SPSS version 20.0 for Mac (SPSS Inc., Chicago, IL, USA).

\section{Results}

Table 1 shows results of the mean $( \pm$ SD) SUL dynamic force production in each position (TRX_40-60, TRX_4080, TRX_60-60 and TRX_60-80) and frequency (60, 70 and $80 \mathrm{bpm}$ ) in the different variables of the study: concentric force, eccentric force, average force and peak force.

\section{Concentric force}

A significant main effect was found for position $\left[F_{(3,27)}\right.$ $=8.284, p=.000, \eta_{\mathrm{p}}^{2}=.47 \mathrm{]}$, but no such effect was found for frequency $\left[F_{(1.28,11.50)}=.854, p=.442, \eta_{\mathrm{p}}{ }^{2}=\right.$ $.08]$, nor for interaction $\left[F_{(6,54)}=.663, p=.681, \eta_{\mathrm{p}}^{2}=\right.$ .06]. Pairwise comparisons showed significant differences between TRX_40-60 and TRX_60-80 ( $p=.008)$ 
Table 1. Force production $(N)$ during dynamic suspended lunge at four different positions and three different frequencies. Values showed in mean \pm SD

\begin{tabular}{|c|c|c|c|c|c|c|}
\hline & \multirow[b]{3}{*}{ Position } & \multicolumn{3}{|c|}{ Dynamic frequency } & \multirow{3}{*}{$\begin{array}{l}\text { Interaction effect } \\
p \\
(p<.05)\end{array}$} & \multirow[b]{3}{*}{$\eta_{p}^{2}$} \\
\hline & & \multirow{2}{*}{$\frac{60 \mathrm{bpm}}{\text { Mean } \pm \text { SD }}$} & \multirow{2}{*}{$\begin{array}{l}70 \mathrm{bpm} \\
\text { Mean } \pm \text { SD }\end{array}$} & \multirow{2}{*}{$\begin{array}{l}80 \mathrm{bpm} \\
\text { Mean } \pm \text { SD }\end{array}$} & & \\
\hline & & & & & & \\
\hline \multirow[t]{4}{*}{ Concentric Force } & TRX_40-60 & $116.21 \pm 37.15$ & $115.81 \pm 32.61^{*}$ & $112.97 \pm 39.06$ & \multirow[t]{4}{*}{.681} & \multirow[t]{4}{*}{.06} \\
\hline & TRX_40-80 & $120.23 \pm 33.02$ & $122.98 \pm 38.40$ & $122.99 \pm 43.88$ & & \\
\hline & TRX_60-60 & $114.74 \pm 32.41$ & $117.40 \pm 36.83 \dagger$ & $119.48 \pm 41.34$ & & \\
\hline & TRX_60-80 & $123.42 \pm 36.87$ & $131.04 \pm 36.84^{*} \dagger$ & $128.41 \pm 35.22$ & & \\
\hline \multirow[t]{4}{*}{ Eccentric Force } & TRX_40-60 & $159.47 \pm 43.69$ & $160.18 \pm 41.64$ & $156.53 \pm 49.67$ & \multirow[t]{4}{*}{.467} & \multirow[t]{4}{*}{.08} \\
\hline & TRX_40-80 & $160.89 \pm 47.19$ & $166.90 \pm 45.78$ & $163.52 \pm 50.31$ & & \\
\hline & TRX_60-60 & $156.82 \pm 38.38$ & $167.05 \pm 47.04$ & $164.49 \pm 52.96$ & & \\
\hline & TRX_60-80 & $162.57 \pm 46.37$ & $178.31 \pm 48.68$ & $166.87 \pm 47.04$ & & \\
\hline \multirow[t]{4}{*}{ Average Force } & TRX_40-60 & $130.56 \pm 39.94$ & $130.03 \pm 36.11^{*}$ & $126.62 \pm 42.91 \mathrm{II}$ & \multirow[t]{4}{*}{.575} & \multirow[t]{4}{*}{.08} \\
\hline & TRX_40-80 & $133.26 \pm 37.77$ & $136.50 \pm 39.56$ & $136.07 \pm 45.94 \mathrm{II}$ & & \\
\hline & TRX_60-60 & $128.57 \pm 34.06$ & $132.45 \pm 40.45 \dagger$ & $133.96 \pm 45.63$ & & \\
\hline & TRX_60-80 & $136.48 \pm 40.84$ & $146.43 \pm 42.06^{*} \dagger$ & $141.21 \pm 39.54$ & & \\
\hline \multirow[t]{4}{*}{ Peak Force } & TRX_40-60 & $205.85 \pm 63.40$ & $215.85 \pm 64.12$ & $221.94 \pm 83.44$ & \multirow[t]{4}{*}{.607} & \multirow[t]{4}{*}{.06} \\
\hline & TRX_40-80 & $207.84 \pm 61.82 \S$ & $223.14 \pm 78.70$ & $233.14 \pm 78.70 \S$ & & \\
\hline & TRX_60-60 & $199.14 \pm 51.15$ & $221.50 \pm 67.47$ & $226.45 \pm 81.88$ & & \\
\hline & TRX_60-80 & $210.63 \pm 61.60 \ddagger$ & $233.24 \pm 68.04 \ddagger$ & $229.65 \pm 72.97$ & & \\
\hline
\end{tabular}

Notes:

$(\mathrm{N})=$ Newton; $\mathrm{bpm}=$ Beats per minute

* Significant differences between TRX_40-60 and TRX_60-80

$\dagger$ Significant differences between TRX_60-60 and TRX_60-80

II Significant differences between TRX $\_40-60$ and TRX $\_40-80$

₹ Significant differences between frequency $60 \mathrm{bpm}$ and $70 \mathrm{bpm}$

$\S$ Significant differences between frequency $60 \mathrm{bpm}$ and $80 \mathrm{bpm}$

and between TRX_60-60 and TRX_60-80 $(p=.021)$ at the frequency of $70 \mathrm{bpm}$ (Table 1).

\section{Eccentric force}

No significant main effects were found for position $\left[F_{(3,}\right.$ 27) $\left.=2.562, p=.076, \eta_{\mathrm{p}}{ }^{2}=.22\right]$, frequency $\left[F_{(2,18)}=3.466\right.$, $\left.p=.053, \eta_{\mathrm{p}}^{2}=.27\right]$ or interaction $\left[F_{(2.41,21.70)}=.834, p=\right.$ $\left..467, \eta_{\mathrm{p}}^{2}=.08\right]$.

\section{Average force}

A significant main effect was found for position $\left[F_{(3,27)}\right.$ $\left.=6.565, p=.002, \eta_{\mathrm{p}}^{2}=.42\right]$, but no such effect was found for frequency $\left[F_{(2,18)}=1.174, p=.332, \eta_{\mathrm{p}}{ }^{2}=.11\right]$, nor for interaction $\left[F_{(6,54)}=.799, p=.575, \eta_{\mathrm{p}}^{2}=.08\right]$. Pairwise comparisons showed significant differences between TRX_40-60 and TRX_60-80 $(p=.007)$, between TRX_60-60 and TRX_60-80 $(p=.020)$ at the frequency of $70 \mathrm{bpm}$ (Table 1). Furthermore, significant differences were found between TRX_40-60 and TRX_40-80 $(p=.036)$ at the frequency of $80 \mathrm{bpm}$ (Table 1$)$.

\section{Peak force}

A significant main effect was found for frequency $\left[F_{(1.22,}\right.$ $\left.{ }_{11.04)}=7.776, p=.004, \eta_{\mathrm{p}}{ }^{2}=.46\right]$ but no such effect was found for position $\left[F_{(3,27)}=1.946, p=.146, \eta_{\mathrm{p}}^{2}=.17\right]$, nor for interaction $\left[F_{(2.68,24.18)}=.594, p=.607, \eta_{\mathrm{p}}{ }^{2}=.06\right]$. Pairwise comparisons showed significant differences $(p<.05)$ between $60 \mathrm{bpm}$ and $80 \mathrm{bpm}$ at TRX_40-80 $(p=.035)$, and between $60 \mathrm{bpm}$ and $70 \mathrm{bpm}$ at TRX_60$80(p=.006)$ (Table 1$)$.

Figure 2 shows the comparison of force production in SULs by the type of contraction (isometric or dy- namic) and by body position (TRX_40-60, TRX_40-80, TRX_60-60 or TRX_60-80), in peak force. A significant main effect was found for contraction type $\left[F_{(1,36)}=\right.$ 52.346, $p=.000, \eta_{\mathrm{p}}{ }^{2}=.59$ ], but not for the interaction effects $\left[F_{(3,36)}=.862, p=.469, \eta_{\mathrm{p}}^{2}=.07\right]$. Pairwise comparisons showed significantly greater peak force in the dynamic SUL than the isometric exercise at TRX_40-60 $(p=.003)$, TRX_40-80 $(p=.000)$, TRX_60-60 $(p=.001)$ and TRX_60-80 $(p=.009)$.

A significant effect was found for position in body mass resistance in isometric SUL $\left[F_{(3,36)}=21.103, p=\right.$ $\left..000, \eta_{\mathrm{p}}{ }^{2}=.64\right]$. Pairwise comparison showed significantly higher percentages of body mass resistance in isometric SUL for the position TRX_40-60 (20.00\% \pm $6.25)$ than for TRX_40-80 $(10.21 \% \pm 1.21, p=.000)$, TRX_60-60 $(10.07 \% \pm 1.21, p=.000)$ and TRX_60-80 $(11.02 \% \pm 1.27, p=.000)$.

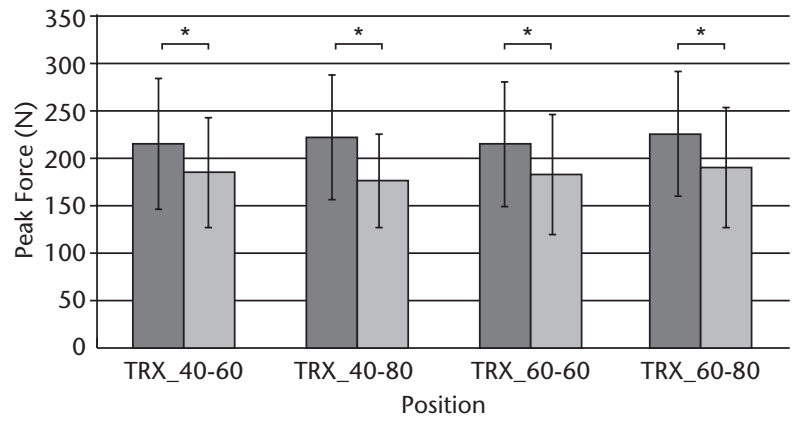

Dynamic contraction type $\quad \square$ Isometric contraction type

Figura 2. Peak force comparison between dynamic and isometric suspended lunge at four different positions. Each bar represents the mean, and the error bar the standard deviation (SD). Note: *Significant differences $(p<.05)$ between dynamic and isometric contraction type 


\section{Discussion}

The main finding of the present study was that position significantly affected average and concentric force production. Force production increased as the distance of the feet and the height of the suspended foot increased. Moreover, the pace of repetitions of a dynamic lunge exercise affected the peak force, but not the other variables analysed. The peak force was significantly higher in the dynamic SUL than the isometric exercise. In addition, body mass resistance was significantly greater in the closest body position in the isometric SUL (TRX_40-60).

Our findings showed that TRX_60-80 position elicited greater force production than TRX_40-60 for all the analysed variables (concentric, eccentric, average and peak force variables). This finding is in accordance with those of authors who have reported greater body mass resistance from position 1 to position 4 in suspended inverted row exercises (Melrose \& Dawes, 2015) and suspended push-ups (Gulmez, 2017). This tendency may be explained by the very body weight and force momentum principles upon which suspended training are based, because the difficulty of ST exercises and the number of motor units recruited depend on the amount of instability caused by the device and the body position (Maté-Muñoz et al., 2014). With regard to strap length, there is a lack of previously published research into force production with a load cell and with strap length variations during ST exercises. However, some evidence suggests there is higher muscle activity when suspension push-ups are performed with a $10 \mathrm{~cm}$ strap length from the floor in than is the case in push-ups at $65 \mathrm{~cm}$ (Borreani et al., 2015; Calatayud et al., 2014). In contrast, the present study showed that a variation in strap length $(40 \mathrm{~cm}$ to $60 \mathrm{~cm}$ ) was not associated with significant differences in force production in any of the variables. This finding suggests that a variation in the strap length of $20 \mathrm{~cm}$ probably does not create a sufficient degree of instability to lead to changes in force production. On the other hand, a variation in feet distance $(60 \mathrm{~cm}$ to $80 \mathrm{~cm}$ ) did lead to greater force production for all the analysed variables. Furthermore, force production was significantly higher at TRX_40-80 (average force) and TRX_60-80 (concentric and average force) than at TRX_40-60 and TRX_60-60, respectively. Another study reported similar force production patterns when the distance between the TRX anchorage point and the foot fulcrum was increased (in 3 to 6 increments of $30.5 \mathrm{~cm}$ ) during a suspended inverted row exercise (Melrose \& Dawes, 2015). We might speculate that increasing the distance of the feet also increases force production when performing a SUL. Nevertheless, variations in feet distance were smaller than those found by Melrose and Dawes (2015). However, a greater distance of the feet would lead to more instability, which would probably lead to inappropriate technique in the performance of SUL.

The results of this study showed that the pace did not significantly alter force variables (concentric, ec- centric, and average force). However, when peak force was analysed, significantly higher force production was achieved between $80 \mathrm{bpm}$ and $60 \mathrm{bpm}$ at TRX_40-80. Likewise, a significantly higher force production was found between $70 \mathrm{bpm}$ and $60 \mathrm{bpm}$ at TRX_60-80. These differences may be explained by the need to apply more force on the SD. Stability needs increase along with the frequency of movement. In fact, the peak force values obtained at $70 \mathrm{bpm}$ and $80 \mathrm{bpm}$ are very similar using TRX_60-80. This finding is in accordance with result obtained by other authors, who have recorded greater muscle activity in those performing lunges under ballistic conditions than those doing the exercises using slow, controlled contractions (Jakobsen et al., 2013). However, the values found among lunge positions are smaller than those reported by LaChance and Hortobagyi (1994) for push-ups and pull-ups. With regard to eccentric force, statistically non-significant results were found. This fact could be explained by the need for controlled braking to keep moving as stable as possible. Nonetheless, our frequency outcomes suggested a trend towards improvement in force production at $70 \mathrm{bpm}$ over the force achieved at $60 \mathrm{bpm}$. There is no corresponding improvement, though, between $70 \mathrm{bpm}$ and $80 \mathrm{bpm}$. Although more evidence is necessary, it seems that 70 bpm could be an optimal frequency to stimulate force production in SUL.

The results of the present study showed significant differences in peak force produced using different contraction types and body positions. Peak force was significantly higher when the participants employed the dynamic contraction type, regardless of body position. This finding is largely consistent with those of Jakobsen et al. (2013) and Jönhagen et al. (2009), who conducted studies of a dynamic lunges done at different paces. These authors reported that high velocity is associated with a higher degree of activity of the muscles analysed in the dynamic lunge. In contrast, as Ekstrom et al. (2007) stated that an isometric lunge elicits lower muscle activity. It appears that dynamic contraction leads to greater force production than isometric contraction, likely because an increase in pace leads to greater recruitment of the motor unit, thus increasing muscle activity. However, there is still a lack of research available investigating the effects of contraction type during suspended exercises. Meanwhile, there is some evidence in the literature that the percentage of body mass resistance increases as a result of the position change during isometric suspended push-ups (Gulmez, 2017) and isometric suspended inverted row (Melrose \& Dawes, 2015). These authors reported that position 4 (body angle closer to the floor) is associated with a greater percentage of body mass resistance from the TRX strap than the other positions $(1,2,3)$, where the body angle is farther from the floor. The results of the present study stand in contrast to those of Melrose and Dawes (2015) and Gulmez (2017), because our findings show that TRX_40-60 (the closest position) was associated with a greater percentage of 
body mass resistance than the other positions (TRX_4080, TRX_60-60, TRX_60-80) during isometric SUL. We expected that body mass resistance would significantly increase as the distance between the feet and the height of the suspended foot increased. Nevertheless, the results suggested that TRX_40-60 provides greater support on the suspension device handles than the other positions. A $9.93 \%$ body mass resistance increase between TRX_40-60 and other positions may explain this outcome. Finally, we could speculate that other positions require the application of more force on the forward foot than on the suspended foot, probably due to increases in strap height and feet distance.

There were some limitations associated with this study. Firstly, only the strap length variations were established to modify the degree of instability from the $\mathrm{SD}$. No comparison between different strap angles was conducted. Another limitation of our data was the lack of quantification of force on the forward leg to compare it to the rear (suspended) leg. In future studies the assessment of ground reaction forces with a force platform may be worth of attention. Finally, another limitation may be the lack of a normalised distance in the forward step during lunge execution, as Boudreau et al. (2009) recommended. However, the thigh and leg length were measured following the ISAK (2001) protocol, thus ensuring the homogeneity of the participants.

In conclusion, the results demonstrate that force production is enhanced when an SUL is performed with a distance of $80 \mathrm{~cm}$ between the feet. Furthermore, there is also evidence from our results to suggest that greater force production during SUL is associated with the choice of pace $(70 \mathrm{bpm})$ and with the use of a dynamic contraction type. Likewise, the assessment of the suspension training load during a lunge seems to be useful for strength and conditioning coaches wishing to individualise the athletes' load related to lunge position and force production. The variations on suspension lunge positions also allow coaches and practitioners to achieve progress through position difficulty. Performing suspended lunges is a good choice for those seeking to strengthen their lower limbs. The inclusion of this exercise in strength and conditioning programs could be useful for those trying to improve their unilateral sport skills such as jumping, changes of direction, sprinting and shooting. Also, leaning the rear leg on the SD in the lunge exercise allows for the creation of higher demands on the FL, thus increasing strength, power and balance. Apart from the changes in the body position, contraction type and pace, coaches and practitioners could increase the muscular and force demands in the suspended lunge by adding other sources of instability (on the front leg) or extra weights.

\section{Conflict of interest statement}

The authors declare that there is no conflict of interest relevant to this study.

\section{Acknowledgements}

We are grateful to all the study participants for their contributions. The research leading to these results was conducted using funds from the Secretaria d'Universitats $i$ Recerca del Departament d'Empresa $i$ Coneixement de la Generalitat de Catalunya i als Fons Socials Europeus under Grant [2018 FI_B 00229]; and Ministerio de Educación, Cultura y Deporte (Beca de Col-laboració) under Grant [311327].

\section{References}

Anderson, G., Gaetz, M., Holzmann, M. \& Twist, P. (2013). Comparison of EMG activity during stable and unstable push-up protocols. European Journal of Sport Science, 13(1), 42-48. doi:10.1080/17461391.2 011.577240

Atkins, S. J., Bentley, I., Brooks, D., Burrows, M. P., Hurst, H. T. \& Sinclair, J. K. (2015). Electromyographic response of global abdominal stabilizers in response to stable- and unstable-base isometric exercise. Journal of Strength and Conditioning Research, 29(6), 1609-1615. doi:10.1519/JSC.0000000000000795

Borreani, S., Calatayud, J., Colado, J., Tella, V., MoyaNájera, D., Martin, F. \& Rogers, M. (2015). Shoulder muscle activation during stable and suspended pushups at different heights in healthy subjects. Physical Therapy in Sport, 16(3), 248-254. doi:10.1016/j. ptsp.2014.12.004

Boudreau, S. N., Dwyer, M. K., Mattacola, C. G., Lattermann, C., Uhl, T. L. \& McKeon, J. M. (2009). Hipmuscle activation during the lunge, single-leg squat, and step-up-and-over exercises. Journal of Sport Rehabilitation, 18(1), 91-103. doi:10.1123/jsr.18.1.91

Byrne, J. M., Bishop, N. S., Caines, A. M., Crane, K. A., Feaver, A. M. \& Pearcey, G. E. P. (2014). The effect of using a suspension training system on muscle activation during the performance of a front plank exercise. Journal of Strength and Conditioning Research, 28(11), 3049-3055. doi:10.1519/JSC.0000000000000510

Calatayud, J., Borreani, S., Colado, J., Martin, F., Batalha, N. \& Silva, A. (2014). Muscle activation differences between stable push-ups and push-ups with a unilateral v-shaped suspension system at different heights. Motricidade, 10(4), 84-93. doi:10.6063/motricidade.10(4).3395

Chulvi-Medrano, I., García-Massó, X., Colado, J., Pablos, C., de Moraes, J. A. \& Fuster, M. A. (2010). Deadlift muscle force and activation under stable and unstable conditions. Journal of Strength and Conditioning Research, 24(10), 2723-2730. doi:10.1519/ JSC.0b013e3181f0a8b9

Cohen, J. (1988). Statistical power analysis for the behavioral sciences. Hillsdale, NJ: Lawrence Erlbaum.

Ekstrom, R. A., Donatelli, R. A. \& Carp, K. C. (2007). Electromyographic analysis of core trunk, hip, and thigh muscles during 9 rehabilitation exercises. Journal of Orthopaedic \& Sports Physical Therapy, 37(12), 754-762. doi:10.2519/jospt.2007.2471 
Escamilla, R. F., Lewis, C., Bell, D., Bramblet, G., Daffron, J., Lambert, S., ... Andrews, J. R. (2010). Core muscle activation during swiss ball and traditional abdominal exercises. Journal of Orthopaedic \& Sports Physical Therapy, 40(5), 265-276. doi:10.2519/ jospt.2010.3073

Gulmez, I. (2017). Effects of angle variations in suspension push-up exercise. Journal of Strength and Conditioning Research, 31(4), 1017-1023. doi:10.1519/ JSC.0000000000001401

ISAK. (2001). Lengths. In International standards for anthropometric assessment (p. 123). Holbrooks, Australia: The International Society for the Advancement of Kinanthropometry.

Jakobsen, M. D., Sundstrup, E., Andersen, C. H., Aagaard, P. \& Andersen, L. L. (2013). Muscle activity during leg strengthening exercise using free weights and elastic resistance: effects of ballistic vs controlled contractions. Human Movement Science, 32(1), 65-78. doi:10.1016/j.humov.2012.07.002

Jönhagen, S., Ackermann, P. \& Saartok, T. (2009). Forward lunge: a training study of eccentric exercises of the lower limbs. Journal of Strength and Conditioning Research, 23(3), 972-978. doi:10.1519/JSC.0b013e3181a00d98

Jönhagen, S., Halvorsen, K. \& Benoit, D. L. (2009). Muscle activation and length changes during two lunge exercises: implications for rehabilitation. Scandinavian Journal of Medicine \& Science in Sports, 19(4), 561-568. doi:10.1111/j.1600-0838.2007.00692.x

LaChance, P. F. \& Hortobagyi, T. (1994). Influence of cadence on muscular performance during push-up and pull-up exercise. Journal of Strength and Conditioning Research, 8(2), 76-79. doi:10.1519/00124278199405000-00003

Marinkovic, M., Bratic, M., Ignjatovic, A. \& Radovanic, D. (2012). Effects of 8-weeks instability resistance training on maximal strength in inexperienced young individuals. Serbian Journal of Sports Sciences, 6(1), 17-21.

Maté-Muñoz, J., Monroy, A., Jodra Jiménez, P. \& Garnacho-Castaño, M. (2014). Effects of instability versus traditional resistance training on strength, power and velocity in untrained men. Journal of Sports Science \& Medicine, 13(3), 460-8.

McCurdy, K., Langford, G. A., Cline, A. L., Doscher, M. \& Hoff, R. (2004). The reliability of 1-and 3RM tests of unilateral strength in trained and untrained men and women. Journal of Sports Science and Medicine, 3, 190-196.

McGill, S., Cannon, J. \& Andersen, J. (2014a). Analysis of pushing exercises: muscle activity and spine load while contrasting techniques on stable surfaces with a labile suspension strap training system. Journal of Strength and Conditioning Research, 28(1), 105-116. doi:10.1519/JSC.0b013e3182a99459
McGill, S., Cannon, J. \& Andersen, J. (2014b). Muscle activity and spine load during pulling exercises: influence of stable and labile contact surfaces and technique coaching. Journal of Electromyography and Kinesiology, 24(5), 652-665. doi:10.1016/j.jelekin.2014.06.002

Melrose, D. \& Dawes, J. (2015). Resistance characteristics of the TRX ${ }^{\mathrm{TM}}$ suspension training system at different angles and distances from the hanging point. Journal of Athletic Enhancement, 4(1), 2-5. doi:10.13140/RG.2.1.4245.1047

Meylan, C. M. P., Nosaka, K., Green, J. \& Cronin, J. B. (2010). Temporal and kinetic analysis of unilateral jumping in the vertical, horizontal, and lateral directions. Journal of Sports Sciences, 28(5), 545-554. doi:10.1080/02640411003628048

Payton, CJ. (2008). Motion analysis using video. In CJ. Payton \& RM. Bartlett (Eds.), Biomechanical evaluation of movement in sport and exercise: The British Association of Sport and Exercise Sciences Guidelines (pp. 17-23). London, United Kingdom: Routledge.

Saeterbakken, A. H. \& Fimland, M. S. (2013). Muscle force output and electromyographic activity in squats with various unstable surfaces. Journal of Strength and Conditioning Research, 27(1), 130-136. doi:10.1519/ JSC.0b013e3182541d43

Snarr, R., Hallmark, A. V., Nickerson, B. S. \& Esco, M. R. (2016). Electromyographical comparison of pike variations performed with and without instability devices. Journal of Strength and Conditioning Research, 30 (12), $3436-3442$. doi:10.1519/ JSC.0000000000001436

Sparkes, R. \& Behm, D. G. (2010). Training adaptations associated with an 8-week instability resistance training program with recreationally active individuals. Journal of Strength and Conditioning Research, 24(7), 1931-1941. doi:10.1519/JSC.0b013e3181df7fe4

Tiainen, K., Sipilä, S., Alen, M., Heikkinen, E., Kaprio, J., Koskenvuo, M., ... Rantanen, T. (2004). Heritability of maximal isometric muscle strength in older female twins. Journal of Applied Physiology, 96(1), 173-180. doi:10.1152/japplphysiol.00200.2003

Tomljanovic, M., Spasic, M., Gabrilo, G. \& Uljevic, O. (2011). Effects of five weeks of functional vs. traditional resistance training on anthropometric and motor performance variables. Kinesiology, 43(2), 145-154.

Vivodtzev, I., Pépin, J. L., Vottero, G., Mayer, V., Porsin, B., Lévy, P. \& Wuyam, B. (2006). Improvement in quadriceps strenght and dyspnea in daily tasks after 1 month of electrical stimulation in severely deconditioned and malnourished COPD. Chest, 129(6), 1540-1548. doi:10.1378/chest.129.6.1540 